\title{
Protocols for Native American Archival Materials
}

IN THE MIDST OF A SPRING SNOWSTORM on April 5, 2006, a group of fifteen Native American, First Nation, and Aboriginal information professionals and scholars and four non-Native archivists gathered at the Northern Arizona University Cline Library (Flagstaff, Arizona) for a series of conversations. ${ }^{1}$ The goal of this invitational conference was to develop best practices for culturally responsive care and use of American Indian archival material held by non-tribal organizations. The participants tackled complex topics, such as the intersection of Native American and Western knowledge systems, to produce a draft document entitled Protocols for Native American Archival Materials. Written from a Native American perspective, the Protocols are intended to inspire and guide archives, libraries, and tribal communities interested in building relationships and in "doing the right thing."

Hundreds of organizations in the United States hold archival collections that document Native American lifeways. Although well-intentioned, non-Indian archivists in mainstream institutions often lack training in the many nuances of caring for such collections-from issues of cultural patrimony to the details of outdated library description practices. On a good day, the information resources allow a medicine man to recapture a lost song, a tribal member to study the evolution of language, or interested members of the public to gain new understanding. On a bad day, a cul-

1. The author would like to acknowledge and extend heartfelt thanks to the contributors to the Protocols project: Kathryn "Jody" Beaulieu (Anishinabe/Ojibwe), Briana Bob (Colville Confederated Tribes), Sheree Bonaparte (Mohawk/ Akwesasne), Steve Crum (Shoshone), Amelia Flores (Mohave), Alana Garwood-Houng (Yorta Yorta), David George-Shongo (Seneca), Eunice Kahn (Diné), Stewart Koyiyumptewa (Hopi), Kim Lawson (Heiltsuk), Robert Leopold, Gloria Lomahaftewa (Hopi), James Nason (Comanche), Lotsee Patterson (Comanche), Richard Pearce-Moses, Willow Roberts Powers, Alyce Sadongei (Kiowa/Tohono O'odham), Jennifer R. Walele (Confederated Tribes of Grande Ronde/ Chinook).

2. The draft document entitled Protocols for Native American Archival Materials can be accessed on the Web at: www2.nau.edu/libnap-p/ or www.firstarchivistscircle.org. The Protocols project received generous support from the American Library Association Office for Diversity, the Gladys Krieble Delmas Foundation, the National Library of Medicine, the Wenner-Gren Foundation, the Bay and Paul Foundations, the Northern Arizona University Institute for Native Americans, and Mary and P. David Seaman. 
turally sensitive photograph of a private Hopi Snake Dance appears in the popular press or an entrepreneur misappropriates a sacred ceremony for commercial gain.

In his book Who Owns Native Culture? Michael F. Brown asks, "How can we promote respectful treatment of native cultures and indigenous forms of self-expression within mass societies?"3 Several professional organizations, such as the Society of American Archivists, American Association for State and Local History, American Anthropological Association, and the Oral History Association, have revised ethical codes to include cultural sensitivity and respect. Drawing upon these codes, the Protocols for Native American Archival Materials address ten policy, legal, and human rights topics:

- the importance of consultation with and concurrence of tribal communities in decisions and policies

- understanding Native American values and perspectives

- rethinking public accessibility and use of some materials

- the need to recognize and provide special treatment for culturally sensitive materials

- providing culturally responsive context

- the role of intellectual and cultural property rights

- the need to consider copying, sharing, and/or repatriation of certain materials

- the recognition of community-based research protocols and contracts

- reciprocal education and training

- raising awareness of these issues within the information professions

The conference participants also consulted international declarations recognizing Indigenous rights, such as The Mata'atua Declaration on Cultural and Intellectual Property Rights of Indigenous Peoples and the seminal Aboriginal and Torres Strait Islander Protocols for Libraries, Archives, and Information Services published in Australia in $1995 .^{4}$

Alana Garwood-Houng, an Indigenous librarian and a co-author of the Australian Protocols, traveled from Canberra to Flagstaff to introduce eleven guidelines for

3. Michael F. Brown, Who Owns Native Culture? (Cambridge: Harvard University Press, 2003): p. 10.

4. Alex Byrne, Alana Garwood, Heather Moorcroft, and Alan Barnes, Aboriginal and Torres Strait Islander Protocols for Libraries, Archives, and Information Services (Deakin, Australia: Australian Library and Information Association for the Aboriginal and Torres Strait Islander Library and Information Resource Network, 1995), www.cdu.edu.au/library/protocol.html; and The Mata'atua Declaration on Cultural and Intellectual Property Rights of Indigenous Peoples, http:/ / aotearoa.wellington.net.nz/imp/mata.htm. See also UNESCO, Convention for the Safeguarding of the Intangible Cultural Heritage, http:/ / unesdoc.unesco. $\mathrm{org} /$ images / 0013/001325/132540e.pdf and the United Nations, Draft Declaration on the Rights of Indigenous People, www.cwis.org/drft9392.html. All Web documents were accessed May 8, 2006. 
handling Aboriginal and Torres Strait Islander records and to share lessons learned from a recent assessment of the Protocols' impact. ${ }^{5}$ The Australian archival record includes painful and personal details of the forced removal of Aboriginal children from biological parents and evidence of stolen land and wages, similar to the histories of many Native peoples in North America. The Australian guidelines provide a model for similar initiatives around the globe.

The information sector in Australia requested the creation of protocols to improve management of Indigenous information resources and to better serve Indigenous communities. After a decade, progress has been made in incorporating the principles in institutional policies and increasing understanding of the issues, but challenges remain in promoting the Australian Protocols, enhancing professional education and training, and achieving representative governance and staffing. ${ }^{6}$

As in the United States, Alex Byrne of the University of Technology, Sydney, observes that there is a wide range of Indigenous perspectives and traditions in Australia. ${ }^{7}$ Each Native American and First Nation band, tribe, and community is distinct. The contributors to the Protocols for Native American Archival Materials were consequently pleased to discover consensus around a number of significant issues.

Unlike Australian Indigenous communities, the sovereign government status and associated human and cultural rights of Native American communities are recognized by federal and state law in the United States and through federal or provincial acknowledgment in Canada. Sovereignty and these rights—including the right to maintain territories, create laws, elect leaders, and engage in "government-to-government" relationships — serve as the foundation for the principles articulated in the Protocols for Native American Archival Materials. ${ }^{8}$

5. Martin Nakata, et al., Mapping the Aboriginal and Torres Strait Islander Protocols for Libraries, Archives, and Information Services (Sydney: University of Technology, 2005), pp. 1-18.

6. Alana Garwood-Houng, "Protocols: Meeting the Challenges of Indigenous Information Needs," in Martin Nakata and Marcia Langton, ed., Australian Indigenous Knowledge and Libraries (Canberra: Australian Academic \& Research Libraries, 2005), pp. 149-57. Interview with Alana Garwood-Houng, Senior Family History Officer, Australian Institute for Aboriginal and Torres Strait Islander Studies, Canberra, Australia, January 24, 2006.

7. Interview with Alex Byrne, Pro-Vice Chancellor (Teaching and Learning) and Vice President (Alumni and Development); Martin Nakata, Director of the Indigenous Academic Development Unit, Jumbunna Indigenous House of Learning; Vicky Nakata, Research Assistant, Jumbunna Indigenous House of Learning; and Gabrielle Gardiner, Library Research and Policy Officer, University of Technology, Sydney, Australia, January 23, 2006.

8. For a discussion of Native American sovereignty, which pre-dates European arrival, see Wallace Coffey and Rebecca Tsosie, "Rethinking the Tribal Sovereignty Doctrine: Cultural Sovereignty and the Collective Future of Indian Nations," Stanford Law and Policy Review 12:2 (2001): 191-210 and Tsianina K. Lomawaima, "Tribal Sovereigns: Reframing Research in American Indian Education," Harvard Educational Review, 70:1 (Spring 2000): 1-21. 


\section{Building Relationships of Mutual Respect}

A strong partnership between a Native American community and a collecting institution involves communication, negotiation, patience, respect, and concurrence. A good meal from time to time is also helpful. Developing an essential trust relationship may take years. Maori scholar Linda Tuhiwai Smith writes in Decolonizing Methodologies that "respect is a reciprocal, shared, constantly interchanging principle which is expressed through all aspects of social conduct." The potential rewards of cooperation, such as the identification of mutually beneficial solutions to common problems, new opportunities for joint projects and resource sharing, and community recovery of traditional knowledge, are worth the effort.

The Protocols provide guidance on how to contact and interact equitably with $\mathrm{Na}$ tive American communities concerning relevant archival materials. The contributors to the best practices concur with Indigenous Curator Liz McNiven of the Australian National Film and Sound Archive who advises, vis-à-vis access and use issues involving Indigenous records, that libraries and archives adopt the precaution-

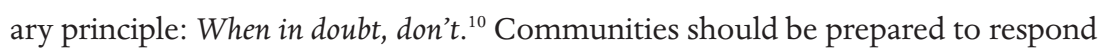
to good-faith efforts to engage in consultation and provide expertise in developing culturally responsive archival management policies.

\section{Striving for Balance in Content and Perspectives}

Dorothy Naranjo, Cultural Preservation Secretary for the Southern Ute Tribe, offered a humorous example of the gulf between Anglo and Native American perceptions at an IMLS-funded Five State American Indian Project: Tribal Libraries, Archives, and Museums meeting. When visitors to her community's cultural center ask why she does not wear feathers and buckskins on a daily basis, she replies, "Same reason you don't wear your pilgrim outfit!"11

Collecting institutions and Native American communities share a commitment to preservation and dissemination of knowledge for present and future generations. However, as Protocols contributor Kim Lawson (Heiltsuk) writes, Indigenous people create, organize, use, and manage knowledge and information resources differ-

9. Linda Tuhiwai Smith, Decolonizing Methodologies: Research and Indigenous Peoples (London: Zed Books, 1999), p. 120.

10. Interview with Liz McNiven, Indigenous Curator, and Mary Miliano, Archivist, Indigenous Collection, National Film and Sound Archive, Canberra, Australia, January 24, 2006. See the draft Protocols for Native American Archival Materials online for all the recommended best practices introduced in this article.

11. Five State American Indian Project: Tribal Libraries, Archives, and Museums. Preserving Our Language, Memory and Lifeways, Heard Museum, Phoenix, Arizona, June 7-9, 2000. 
ently from Western libraries and archives. Privileged access to information based on gender, initiate status, age, clan, society, and role can be a form of protection for a community, in contrast to the American democratic traditions of open access to information resources and intellectual freedom. ${ }^{12}$

Rather than view these approaches as irreconcilable, the Protocols seek to build bridges among multiple perspectives, core values, and the sometimes competing forces of a pluralistic society. Indigenous Australian solicitor Terri Janke urges us to "debate these issues and find a balance between the needs of Indigenous and traditional communities as well as relevant cultural policy interest issues from the whole of society." ${ }^{13}$ What should archivists and librarians do when intellectual freedom comes into conflict with individual or community privacy or with religious freedom? What should the balance be between preservation and access in perpetuity in a collecting institution and the reality that in some Native cultures not everything should be preserved or shared?

The Protocols advise collecting institutions to acquire contemporary scholarship from the Indigenous perspective, to value both Native American and Western knowledge management systems, and to re-examine assumptions about existing archival practice. Communities, in turn, are encouraged to recognize the positive role institutions can play in cultural revitalization and preservation of documentary heritage.

\section{Accessibility and Use}

Archivists and librarians disquieted by requests to rethink access or use of Native American archival materials may find parallels in the kinds of restrictions that have been employed by collecting institutions for decades: honoring donor wishes; respecting privacy or confidentiality; determining that material is too fragile to withstand use; complying with state and federal laws; and protecting the integrity of a collection or the institution. Restrictions are often fluid and change over time. The potential to slide down the slippery slope of censorship is not new.

12. Kimberley L. Lawson, Precious Fragments: First Nations Materials in Archives, Libraries, and Museums (M.A. thesis, University of British Columbia, 2004), pp. v-ix, 1. The Protocols acknowledge that collecting institutions have a history of caring for restricted, confidential, or sensitive materials that may or may not be affiliated with Native American communities. The American Library Association defines intellectual freedom as "the right of every individual to both seek and receive information from all points of view without restriction. It provides for free access to all expressions of ideas through which any and all sides of a question, cause or movement may be explored." Accessed online May 13, 2006 at: Intellectual Freedom Basics, www.ala.org/ala/oif/basics/Default2272.htm.

13. Nakata and Langton (2005), p. 109. See also Terri Janke, Our Culture, Our Future: Report on Australian and Indigenous Cultural and Intellectual Property Rights (Surrey Hills: Michael Frankel, 1998). 
Professional codes of ethics advocate neutrality and equal access, with an appreciation for cultural sensitivities. ${ }^{14}$ The Protocols discuss the need to work together to ensure that libraries and archives hold the "right of possession," as the original collecting may have involved individual or community misunderstanding, deception, or subterfuge. If questions exist about ownership and informed consent, the rights of the community of origin must take precedence. The Protocols also suggest ways to improve services to Native American communities, including reviewing commercial use of affiliated collections and offering a portion of any revenue received.

\section{Culturally Sensitive Materials}

Most, if not all, Native Americans view their world as an integrated whole-with no separation of the spiritual from the secular. The unregulated release of sensitive information may lead to exploitation as well as community and personal harm. For instance, revealing privileged information may have a negative impact on the spiritual well-being of non-initiated Indigenous youth. The Protocols instruct that consultation with communities of origin is the key to identifying and caring for sacred, secret, or sensitive information resources that have been removed from their cultural context. ${ }^{15}$

California State University at Chico adopted an innovative approach to preparing the archival collection of anthropologist Dorothy Moorehead Hill for public access. Hill's 4,000 photographs, 350 audio recordings, field notes, and related materials pertain to the Maidu, Pomo, and Wintun and are of great value to communities and to scholars. Chico Provost Scott McNall appointed a 12-member committee, composed of university personnel, members from the three tribes, and the Hill family "to decide, photo by photo and tape by tape, what constitutes 'sensitive items."”16 The committee views the joint review process as an opportunity for healing past animosity and distrust.

14. The following professional ethical codes were accessed online May 12, 2006: American Anthropological Association, www.aaanet.org/committees/ethics/ethcode.htm; American Association for State and Local History, www.aaslh.org/ethics.htm; American Library Association, www.ala.org/ala/oif/ statementspols/codeofethics/codeethics.htm; Council for the Preservation of Anthropological Records, Ethical Use of Anthropological Records (CoPAR Bulletin 10), www.nmnh.si.edu/naa/copar/bulletin10.htm; Oral History Association, Evaluation Guidelines, www.dickinson.edu/oha/pub_eg.html; and Society of American Archivists, www.archivists.org/governance/handbook/app_ethics.asp.

15. In Hopi culture, a pregnant woman can be endangered by viewing images of a Snake Dance. The National Museum of the American Indian makes allowances for sensitive material, such as requesting that male warrior society objects not be handled by women during their "moon" (menstrual) cycle. James Pepper Henry, "Challenges in Managing Culturally Sensitive Collections at the National Museum of the American Indian," in Lawrence E. Sullivan and Alison Edwards, Stewards of the Sacred (Washington, DC: American Association of Museums, 2005), pp. 105-12.

16. Taran March, "A Legacy in Trust: The Dorothy Moorehead Hill Collection," Chico Statements (Spring 2002). Accessed online May 13, 2006 at: www.csuchico.edu/pub/cs/spring_02/site_map.html. The Protocols contributors would recommend that a joint review committee be structured so that Native American community members are equal partners with university personnel. 
The contributors to the Protocols recommend that researchers obtain approval from communities before accessing culturally sensitive materials. In 1991 the Northern Arizona University Cline Library and the Hopi Tribe entered into a voluntary agreement whereby requests to reproduce ceremonial photographs require written permission from the Hopi Cultural Preservation Office. The photographs can still be viewed onsite but not online. The Protocols incorporate Alyce Sadongei's (Kiowa/Tohono O'odham) observations that "sacred objects ... often require special care that cannot be reduced to a list of 'do's' and 'don'ts." Such care may involve burning sage or cedar, making offerings of corn pollen, or designing specialized storage. Collecting institutions should accommodate the needs of religious or cultural practitioners but avoid attempting ritual care on behalf of a community. ${ }^{17}$

\section{Providing Context}

The importance of providing culturally appropriate context for archival materials hit home when a young Navajo student came to my office in tears and asked why photograph titles in the Cline Library's digital archives contained derogatory words such as "squaw" and "buck." A discussion of Anglo American Cataloging Rules 2nd Edition and prescriptive use of original titles offered little comfort. Much can be done to annotate and modify catalog records and finding aids, while still adhering to established library and archival descriptive practice. Kim Lawson astutely observes that "gaps and silences are just as important as the information and records which are accessible. Museums, libraries and archives practices do not lend themselves to cataloguing or describing silences." ${ }^{18}$

The Protocols recommend that libraries, archives, and Native American communities enhance context ${ }^{19}$ with:

- cultural sensitivity statements that alert researchers to community perspectives and applicable protocols

- notice of potentially offensive content (communities need to understand, however, that injurious information may be inherent in the original content of the resources)

- respectful and culturally specific terminology

17. Alyce Sadongei, in Sherelyn Ogden, Caring for American Indian Objects: A Practical and Cultural Guide (St. Paul: Minnesota Historical Society Press, 2004), pp. 17-19.

18. Lawson (2004), p. 7. See also Hope Olson, The Power to Name: Locating the Limits of Subject Representation in Libraries (Dordrecht: Kluwer, 2002).

19. In Australia, Indigenous and non-Indigenous librarians constructed a national thesaurus for describing Aboriginal and Torres Strait Islander records. See Heather Moorcroft and Alana Garwood, Aboriginal and Torres Strait Islander Thesaurus (Canberra: National Library of Australia, 1997). Interview with Hilary Rowell, Assistant Director, Access Projects, National Archives of Australia, Canberra, Australia, January 24, 2006. 
- substitute language or explanations of potentially inflammatory statements

- background regarding the nature of the creation of the archival material and its disposition with the collecting institution

- detailed identification of Native American people, places, and events

\section{Native American Intellectual Property Issues}

The protection of Indigenous traditional knowledge and cultural heritage is gaining ground internationally. One need only consult the Model Law for the Protection of Traditional Ecological Knowledge, Innovations, and Practices for arguments in favor of a new paradigm for tangible and intangible property rights. ${ }^{20}$ As Protocols contributor James D. Nason (Comanche) notes in Borrowed Power: Essays on Cultural Appropriation, "What is required at this moment is a fundamental acceptance that intellectual property and most especially esoteric knowledge are vital components of the living cultural heritage of Native American communities ... a way must be found to acknowledge and implement appropriate Native American controls over such knowledge." 21

U.S. copyright law causes concern for Native American communities on several counts. First, copyright expires. From a community standpoint, some traditional knowledge should be protected in perpetuity. Copyright safeguards authors or publishers but not the subjects of creative work. Additionally, current laws fail to address such issues as communal ownership, distribution of culturally sensitive or secret information, historic works, and oral or intangible works. ${ }^{22}$ The Protocols explore the notion of expanding moral rights through the droit moral- the right to attribution and to maintain the integrity of a work-as a way to enhance protection. The droit moral is perpetual and applies in a limited way to American creators of visual art. ${ }^{23}$

Digital technology has generated new intellectual property concerns for Native American communities. Arun Agrawal cautions that "just because some material

20. Model Law for the Protection of Traditional Ecological Knowledge, Innovations, and Practices, accessed May 12, 2006, at: www.grain.org/brl_files/brl-model-law-pacific-en.pdf.

21. James D. Nason, "Native American Intellectual Property Rights: Issues in the Control of Esoteric Knowledge," in Bruce Ziff and Pratima V. Rao, ed., Borrowed Power: Essays on Cultural Appropriation (New Brunswick: Rutgers University Press, 1997), p. 252. See also James D. Nason, "Traditional Property and Modern Laws: The Need for Native American Community Intellectual Property Rights Legislation," Stanford Law and Policy Review 12:2 (2001): 255-66.

22. See Tom Greaves, ed., Intellectual Property Rights for Indigenous Peoples: A Source Book (Oklahoma City: Society for Applied Anthropology, 1994); Terri Janke, "Managing Indigenous Knowledge and Indigenous Cultural and Intellectual Property," in Nakata and Langton, Australian Indigenous Knowledge, pp. 99-111; and Robert C. Lind, et al., Art and Museum Law (Durham: Carolina Academic Press, 2002).

23. See 17 USC Section 106A, Visual Artists Rights Act of 1990. 
is in the public domain and even out of copyright protection, doesn't necessarily mean that it is appropriate to circulate freely on the web or with little or no restriction or moderation. ${ }^{24}$

\section{Copying and Repatriation of Records to Native American Communities}

Many Native American communities express frustration over limited access to cultural heritage and documentation housed in cities, often far away from home. The best practice identified in the Protocols states that libraries and archives should "Respond cooperatively to requests for copies of records for community use and retention.” Repatriating (the act of returning) copies works well in the digital world.

The Protocols go further to recommend repatriation of original documents upon request from a Native American community in cases of theft, clear lack of evidence of ownership, or for archival materials held in trust for communities. Collecting institutions may need to retain copies of repatriated material for legal purposes, but communities would establish conditions for access and use.

The Protocols include a brief discussion of the 1990 federal Native American Graves Protection and Repatriation Act (NAGPRA) as a potential model for engaging in conversation and voluntary action. NAGPRA recognizes tribal sovereignty and pertains to legal rights, including the right of repatriation, and protection for Native American human remains, associated funerary objects, and "cultural patrimony" (an object having ongoing historical, traditional, or cultural importance). ${ }^{25}$ Do images, field notes, sketches, and other items that are associated with human remains and funerary objects fall under NAGPRA?

This legislation makes no specific mention of archival records or traditional knowledge. To date, the definitions of "cultural patrimony" and "associated objects" in the context of archival materials have yet to be tested in court or through the national NAGPRA committee. According to David Hurst Thomas, a curator at the American Museum of Natural History, "NAGPRA remains a very murky piece of legislation, and clarifying it will be a bumpy political process." ${ }^{26}$ Though NAGPRA

24. Nakata and Langton (2005), p. 87.

25. See "Native American Graves Protection and Repatriation Act" (43 CFR Part 10) accessed May 15, 2006, at: www.cr.nps.gov/nagpra.

26. David Hurst Thomas, Skull Wars: Kennewick Man, Archaeology, and the Battle for Native American Identity (New York: Basic Books, 2000), p. 275. See also Tom Greaves, "Examining Indigenous Rights to Culture in North America," Cultural Dynamics, 14:2 (2002): 121-42 and James D. Nason, "Beyond Repatriation: Cultural Policy and Practice for the Twenty-First Century," in Ziff and Rao. Cultural Appropriation, pp. 291-312. 
does not mention documentary heritage, it remains an open question about the applicability of the act to archives and libraries.

The Protocols emphasize positive relationship building and negotiation to resolve problems. Some collecting institutions have voluntarily returned documents or images related to burials or human remains in the spirit of NAGPRA. Native American communities should be prepared to provide appropriate care for copied and repatriated items. Communities may ask libraries and archives to enter into cocustody arrangements or retain records on behalf of communities that lack proper facilities for preservation and access.

This section of the Protocols may elicit debate among information professionals. For those times when Cline Library personnel grapple with archival dilemmas, Stewart Koyiyumptewa (Hopi) presented a T-shirt that reads: "Don't Worry Be Hopi!"

\section{Native American Research Protocols}

To defend against misappropriation, unauthorized commercial use, and misrepresentation of specialized or traditional knowledge, many Native American nations and communities have drafted formal and informal policies and procedures to govern research by external parties. Collecting institutions may also have experience working with review boards for projects involving human subjects and complying with federal requirements to receive grants. Everyone benefits when researchers adopt the highest ethical standards and enter into agreements concerning informed consent, confidentiality and privacy, ownership of physical and intellectual products, disposition of research materials, the right of review, employment, and future projects. $^{27}$

Best practices for Native American communities and collecting institutions include developing, publicizing, and adhering to research protocols; encouraging communication between researchers and communities; and working with potential donors to document prior community understandings and to obtain copies of research agreements or contracts.

\section{Reciprocal Education and Training}

Protocols contributor Lotsee Patterson (Comanche), who teaches library science at the University of Oklahoma, is part of a growing international group of academics

27. James D. Nason, "Tribal Research: Tribal Models for Controlling Research,” Tribal College Journal, 8:2 (Fall 1996): 16-20. The Apache, Hopi, Navajo, and Zuni, among other tribes, have developed research protocols in recent years. See also Phyllis Mauch Messenger, ed., The Ethics of Collecting Cultural Property: Whose Culture? Whose Property? (Albuquerque: University of New Mexico, 1999). 
who are passionate about acknowledging, exploring, and integrating Indigenous constructs for managing knowledge in information science programs. She argues that schools need to offer "curricula that are relevant to today's clientele in libraries and information centers ... Participation in this effort presents an opportunity to make the next century better for library services to native people." ${ }^{28}$

Native American knowledge workers, as well as spiritual and cultural leaders, can help educate those who care for relevant archival materials. Libraries and archives can assist communities in developing knowledge centers. Cross-cultural exchange will enrich the information landscape.

The Protocols recognize the pressing need to train and support, formally and informally, American Indian librarians and archivists and to change the face of mainstream institutions to include tribal representation at all levels of governance and staffing. The contributors highlighted several noteworthy programs and initiatives, such as Knowledge River at the University of Arizona; Honoring Generations: Developing the Next Generation of Native Librarians at the University of Texas at Austin; the School of Library and Information Studies at the University of Oklahoma; and the American Library Association's Spectrum Initiative. ${ }^{29}$

\section{Awareness of Native American Communities and Issues}

The Protocols are written to assist in raising awareness of "issues surrounding the collection, ownership, preservation, handling, access, and use of physical and digital American Indian archival resources." Native American communities, libraries, and archives are encouraged to cooperate to problem-solve, share resources and expertise, gather and disseminate cultural heritage in culturally responsive ways, promote lifelong learning and understanding, and create stronger cross-cultural bonds. A first step may involve reciprocal visits.

\section{Next Steps}

The contributors to the Protocols for Native American Archival Materials look forward to initiating a robust national conversation around these topics. The draft docu-

28. Lotsee Patterson, "History and Status of Native Americans in Librarianship," Library Trends, 49:1 (Summer 2000): 182-93.

29. Consult the Knowledge River program (http:/ / knowledgeriver.arizona.edu/) at the University of Arizona; Honoring Generations: Developing the Next Generation of Native Librarians (www.ischool.utexas. edu/ hg/index.html) at the University of Texas at Austin; the School of Library and Information Studies (www.ou.edu/cas/slis) at the University of Oklahoma; the American Library Association Spectrum Initiative (www.ala.org/ala/diversity/spectrum/spectruminitiative.htm); and Index of Native American College Resources, www.hanksville.org/NAresources/indices/NAcollege.html. All Web sites were accessed May 15, 2006. 
ment serves as a beginning for promoting ethical, mutually beneficial care of Native American archival collections. The Protocols will be presented to professional organizations and communities for comment, refinement, and endorsement. The contributors appreciate that each collecting institution and community will need to adopt and interpret the best practices to suit local circumstances. Implementation will test the validity and viability of the Protocols. ${ }^{30}$

Throughout the discourse, archivists and librarians should keep in mind the unique status of Native American communities as sovereign governments with associated rights and embrace the power of building relationships. A successful Protocols project will result in enhanced understanding at the national level of Native American concerns around appropriate care and use of archival collections and information resources housed in nontribal repositories; increased cooperation between tribal communities and nontribal libraries, archives, and museums; and the generation of new models for shared stewardship. As Sven Haakanson, Jr. (Alutiiq/Sugpiaq) reinforces, "it takes human connections to make positive changes happen." ${ }^{1}$

30. The First Archivists Circle, a non-profit organization compose of Native American and tribal archivists, will serve as home for the Protocols.

31. Ogden (2004), p. 15.

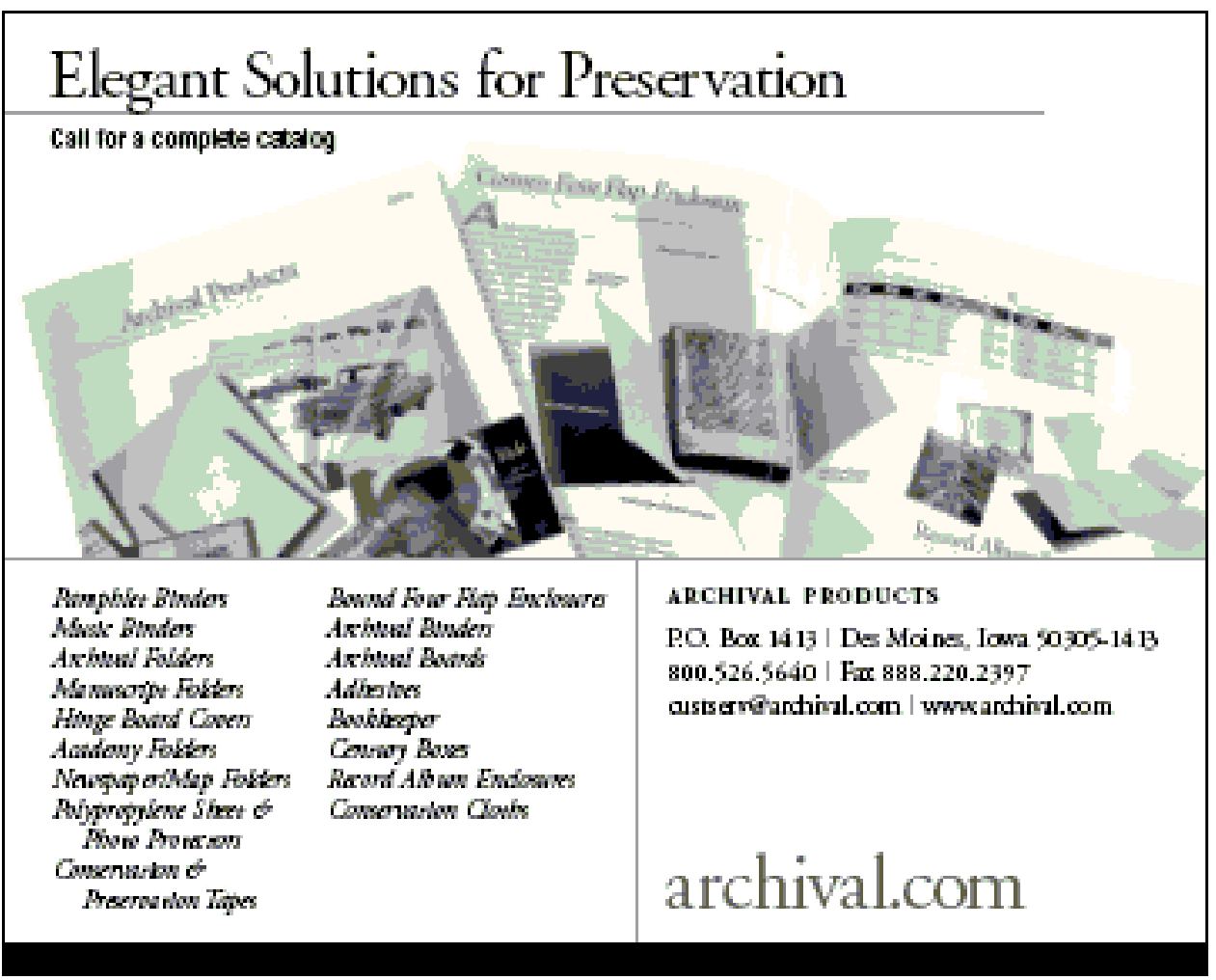

